This document is the Accepted Manuscript version of a Published Work that appeared in final form in British Journal of Nursing, copyright (C) MA Healthcare, after peer review and technical editing by the publisher. To access the final edited and published work see https://doi.org/10.12968/bjon.2019.28.4.250.

\title{
Are mentors failing to fail underperforming student nurses? An integrative
}

$\underline{\text { literature review }}$

Wray, Jane; Kennedy, Michelle; North, Hannah

\section{$\underline{\text { Introduction }}$}

Ensuring that pre-qualifying nurses achieve proscribed standards for safe and competent practice is essential for nurse education and practice in the UK (Nursing and Midwifery Council (NMC) 2015, 2017) and internationally (Clark et al. 2011; Zasadny and Bull 2015; Nursing and Midwifery Board of Australia 2018). Competency based education aims to generate a nursing workforce with the skills and flexibility to function within global markets (Foth and Holmes 2016) and fulfil employer requirements for graduates who are fit to commence employment without the need for extensive further training (Black et al. 2008). Competency based education focuses on what nurses need to know to function safely and effectively in the clinical environment (Foth and Holmes 2016) and can be defined as; 'Broad clusters of general attributes which are considered essential for effective performance' (Garside and Nhemachena 2013, p. 543).

Student nurses are required to demonstrate effective application of knowledge, judgement and skill (Paganini and Egry 2011) and achieve set learning outcomes to advance on their programme of study and ultimately qualify to practice independently (Gravina 2017). Assessment in clinical practice is centred on performance, with competency offering a mechanism for its measurement (Clark et al. 2011). However, assessing competence in practice is complex (Hunt et al. 
This document is the Accepted Manuscript version of a Published Work that appeared in final form in British Journal of Nursing, copyright (C) MA Healthcare, after peer review and technical editing by the publisher. To access the final edited and published work see https://doi.org/10.12968/bjon.2019.28.4.250.

2012). There is a difference between assessing a students' technical competence to perform certain skills (e.g. applying a wound dressing) in comparison to judging professional attitude and behaviour. The latter is more subjective (Elliott 2015) and 'impressionistic' (Burden et al. 2017).

In the UK, mentors have an academic, legal, and professional responsibility to teach, supervise and evaluate students' clinical performance (Tanicala et al. 2011; Cant et al. 2013; Zasadny and Bull 2015). They are required to complete an approved mentor preparation programme demonstrating that they have integrated the NMC (2008) standards into their own practice to maintain their status on the 'active' register (Andrews et al. 2010). All qualified nurses are expected to work within the limits of their competence, recognising and reporting unsafe care delivered by other registered professionals (NMC 2015) including that of students (Tanicala et al. 2011). A mentor should only confirm a student as proficient if they feel that they have achieved the required standards of competency (NMC 2008). If a mentor 'fails to fail' a poorly performing student there are significant implications for patient protection and safety as well as legal implications and consequences (Larocque and Luhanga 2010). This is a key concern in the wake of patient safety scandals in the UK (Francis 2013, Gosport Independent Panel 2018). Competency standards enshrined in professional regulatory documents are underpinned by nursing ethics protecting patients from potential harm (Hunt et al. 2012). Ensuring that under-performing students do not become registered nurses is part of the mentors' role, although not explicitly referred to in the NMC guidance (NMC 2008). 
This document is the Accepted Manuscript version of a Published Work that appeared in final form in British Journal of Nursing, copyright (C) MA Healthcare, after peer review and technical editing by the publisher. To access the final edited and published work see https://doi.org/10.12968/bjon.2019.28.4.250.

Mentors concerns regarding under-performing students and the phenomena of 'failing to fail' has been previously identified and discussed in the literature (Lankshear 1990; Duffy 2003; Scholes and Albarran 2005; Skingley et al 2007). Duffys' (2003) grounded theory study highlighted the issue of 'failure to fail' and identified reasons for this phenomena including; a lack of confidence, unwillingness to invest time required to fail a student, university over-turning the mentors' decision, and the emotional impact of failing a student. This study alongside others (Hawe 2003, Scanlan et al. 2001) informed the NMC's 'Standards to Support Learning and Assessment in Practice' (2008). This framework aimed to enhance quality of learning in practice, address mentor preparation and support, and increase mentor awareness of their role. It was clear that mentors were accountable for confirming whether the student had or had not met the required standards for safe and competent practice (NMC 2015). It is not clear however how successfully or consistently the NMC guidance (2008), available since 2008 has been implemented as the issue of 'failure to fail' continues to be discussed (Gainsbury 2010; Vinales 2015; Elliott 2016; Peate 2018). The revised Nurse Education and Assessment Standards in the UK due for implementation in 2019 (NMC 2018) have reignited this debate. These will inevitably impact upon the role of the mentor, including possible removal of the title 'mentor' and separation of the supervisory role from that of assessment. Consequently, it is timely to review this issue and determine the nature of the current evidence base to inform future practice. This review posed the following question; "What is the evidence that mentors are failing to fail underperforming student nurses?' 
This document is the Accepted Manuscript version of a Published Work that appeared in final form in British Journal of Nursing, copyright (C) MA Healthcare, after peer review and technical editing by the publisher. To access the final edited and published work see https://doi.org/10.12968/bjon.2019.28.4.250.

\section{Study Method}

An integrated literature review was undertaken using a systematic approach using the following online-data bases; Medline, Scopus, Psyclnfo, and Cumulative Index to Nursing and Allied Health Literature (CINAHL). The search was conducted between December 2015 and February 2017 and key words included; mentors, mentoring, students, nurses, nursing, assessment, competence, failure, failing, failure to fail. Boolean operators ('And', 'Or', 'Not') were used to combine or exclude keywords in addition to truncation (Craig and Smyth 2011). Inclusion and exclusion criteria were applied to focus the search and ensure inclusion of relevant papers (Aveyard 2014) (see Table 1).

\section{INSERT TABLE 1}

Table 1. Inclusion/exclusion criteria

\begin{tabular}{|l|l|}
\hline Inclusion criteria & Exclusion Criteria \\
\hline Primary Research & Not primary research \\
\hline English language papers only & Non-English language papers \\
\hline Peer Reviewed & Non-peer reviewed \\
\hline Published after 2008 & $\begin{array}{l}\text { Published before the 2008 NMC } \\
\text { Guidance }\end{array}$ \\
\hline
\end{tabular}


This document is the Accepted Manuscript version of a Published Work that appeared in final form in British Journal of Nursing, copyright (C) MA Healthcare, after peer review and technical editing by the publisher. To access the final edited and published work see https://doi.org/10.12968/bjon.2019.28.4.250.

Only primary research was included as the review was concerned with surfacing evidence rather than commentary, however no restrictions were applied to study type or design. Papers published prior to the revised NMC guidance (in 2008) were excluded as the evidence on this topic had already been reviewed, thus a contemporary perspective was sought. Database searching was combined to remove duplicates. Only a limited number of eligible papers were identified therefore, secondary searching was conducted via hand searching of journals and reference lists (Aveyard 2014). Following screening of titles, 12 relevant papers were identified. Further screening of the abstracts resulted in 7 further papers being excluded as not relevant to the review question or did not meet the inclusion criteria. Full text reading of the remaining 5 papers was undertaken prior to extraction of data. The search strategy and results are shown in Figure 1 (PRISMA diagram).

INSERT FIGURE 1 (PRISMA DIAGRAM) 
This document is the Accepted Manuscript version of a Published Work that appeared in final form in British Journal of Nursing, copyright (C) MA Healthcare, after peer review and technical editing by the publisher. To access the final edited and published work see https://doi.org/10.12968/bjon.2019.28.4.250.

\section{PRISMA DIAGRAM}

\section{Search 1}

Records identified through database searching EBSCO Host

$=9$ papers

'Nurses failing students' 'and' 'mentor'

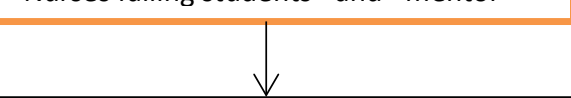

Papers after records excluded $=1$

Reason for exclusion= Papers not relevant to mentoring. Reflective accounts of mentoring and no relevance to failure to fail.

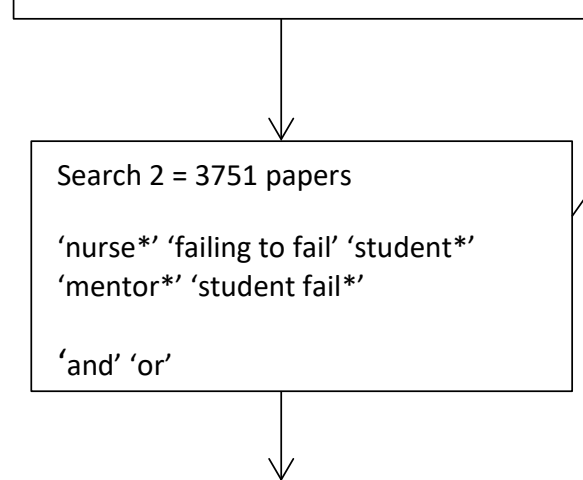

Search $3=835$ papers

'failing student*' 'assessment' 'assessing' 'competence' 'fail"' 'mentor*' ' nursing students' Records screened $=9$

Updated search

Search limited to years of publication2008-2016

$=938$ papers

Records excluded $=76$

Records after papers excluded $=6$

Reasons for exclusion = duplicate papers, no relevance to topic area, articles, reflective papers.

'and' 'or'

Records screened $=82$

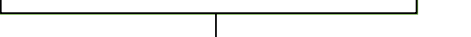

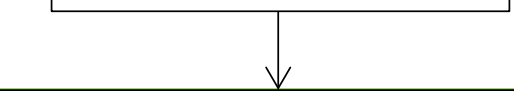

Records used $=0$

Reason for exclusion = no relevance, based on failing dentistry students, social workers, foreign papers, based on assessment and competence of mentors, not failing to fail.

Additional papers identified through

Other sources

$=5$ papers

Papers excluded $=7$

Reasons for exclusion = duplications, no

relevance to failure to fail, not based on

nursing students.

Papers assessed for eligibility

$=12$ papers 
This document is the Accepted Manuscript version of a Published Work that appeared in final form in British Journal of Nursing, copyright (C) MA Healthcare, after peer review and technical editing by the publisher. To access the final edited and published work see https://doi.org/10.12968/bjon.2019.28.4.250.

Three of the papers were qualitative exploratory studies (Jervis and Tilki 2011;

Larocque and Lahanga 2013; Black et al. 2014). Both Jervis and Tilki (2011) and Larocque and Lahanga (2013) used semi-structured interviews with 14 and 13 participants respectively. Black et al (2014) interviewed 19 mentors using reflective interviews to explore the emotional and psychological aspect of failing a student nurse. Of the remaining two papers; Brown et al. (2012) surveyed 1790 mentors using a 29-item questionnaire to elicit data and Lawson (2010) used mixed methods (interviews and pre-post workshop questionnaires) to explore the challenges that nurses $(n=193)$ and allied health professionals $(n=90)$ faced. The five papers included indicated that whilst there is some existing evidence that explores failure to fail, the majority is comprised of small scale, localised studies. All papers were UK based studies, with the exception of Larocque and Lahanga (2013) which was Canadian. Although subject to a different regulatory body (The Canadian Nurses Association), Canada has a similar educational system to the UK and provided a useful non-UK comparison. The Critical Appraisal Skills Programme tool (CASP) was used to appraise the papers and identify relevant characteristics prior to thematic analysis. These are shown in Table 2 (Study Characteristics table).

INSERT TABLE 2: STUDY CHARACTERISTICS TABLE 
Table 2: Study Characteristics Table

\begin{tabular}{|c|c|c|c|c|}
\hline $\begin{array}{l}\text { Author(s), } \\
\text { country }\end{array}$ & Aim & $\begin{array}{l}\text { Study design / } \\
\text { methodology }\end{array}$ & Key findings & $\begin{array}{l}\text { Strengths (+) and } \\
\text { limitations (-) }\end{array}$ \\
\hline $\begin{array}{l}\text { Jervis.A } \\
\text { Tilki.M } \\
(2011)\end{array}$ & $\begin{array}{l}\text { To explore } \\
\text { reasons } \\
\text { why } \\
\text { mentors } \\
\text { were failing } \\
\text { to fail poorly } \\
\text { performing } \\
\text { students, } \\
\text { with a view } \\
\text { to identify } \\
\text { the support } \\
\text { needed to } \\
\text { help them } \\
\text { make } \\
\text { difficult } \\
\text { assessment } \\
\text { decisions. }\end{array}$ & $\begin{array}{l}\text { Qualitative } \\
\text { Approach. } \\
\text { Local small-scale } \\
\text { exploratory study. } \\
\text { Two methods of } \\
\text { data collection:- } \\
\text { 1) Focus Group. } \\
\text { 2) Individual } \\
\text { semi-structured } \\
\text { interviews } \\
\\
\text { Purposive } \\
\text { sampling from the } \\
\text { current 'live } \\
\text { register' of } \\
\text { mentors } \\
\text { Sample size = 14 } \\
\text { mentors } \\
\text { Criteria for } \\
\text { inclusion = stage } \\
2 \text { mentors who } \\
\text { had mentored at } \\
\text { least } 3 \text { pre- } \\
\text { registration } \\
\text { students in the } \\
\text { previous } 2 \text { years } \\
\text { Participants = } \\
\text { district nurses; } \\
\text { health visitors; } \\
\text { ward nurses; }\end{array}$ & $\begin{array}{l}\text { Three themes } \\
\text { emerged from this } \\
\text { study:- } \\
\text { 1) The complexity of } \\
\text { assessing students. } \\
\text { 2) The difficulty of } \\
\text { assessing attitudes. } \\
\text { 3) Confidence about } \\
\text { assessment } \\
\text { decisions. } \\
\text { * Assessing clinical } \\
\text { performance is } \\
\text { complex, especially } \\
\text { when the student } \\
\text { performance is } \\
\text { border-line. } \\
\text { * Mentors have } \\
\text { difficulties with the } \\
\text { assessment of } \\
\text { students' attitudes. } \\
\text { * Deciding to fail/refer } \\
\text { an assessment is } \\
\text { stressful, but the } \\
\text { response of the } \\
\text { student makes it } \\
\text { more difficult. } \\
\text { * Organisational, } \\
\text { professional and } \\
\text { personal factors } \\
\text { impact on confidence } \\
\text { when referring poorly } \\
\text { performing students. }\end{array}$ & $\begin{array}{l}\text { (+) Semi-structured } \\
\text { interviews facilitated } \\
\text { further exploration of } \\
\text { issues initially raised in } \\
\text { the focus group (some } \\
\text { mentors were unwilling } \\
\text { to discuss their } \\
\text { sensitivities in a group) } \\
\text { increasing validity. } \\
\text { (+) Researchers have } \\
\text { appropriate } \\
\text { experience. } \\
\text { (+) Interviews arranged } \\
\text { at a time and place } \\
\text { convenient for the } \\
\text { participant's. } \\
\text { (+)All mentors had at } \\
\text { least mentored at least } \\
\text { three pre-registration } \\
\text { students. } \\
\text { (+) A range of nursing } \\
\text { professionals; ward } \\
\text { nurses, district nurses } \\
\text { and health visitors } \\
\text { were involved, } \\
\text { increasing validity. } \\
\text { (-) Researcher was } \\
\text { known to the } \\
\text { participant's-some } \\
\text { participant's may not } \\
\text { have said what they } \\
\text { wanted to say, } \\
\text { therefore potentially }\end{array}$ \\
\hline
\end{tabular}


This document is the Accepted Manuscript version of a Published Work that appeared in final form in British Journal of Nursing, copyright (C) MA Healthcare, after peer review and technical editing by the publisher. To access the final edited and published work see https://doi.org/10.12968/bjon.2019.28.4.250.

\begin{tabular}{|c|c|c|c|c|}
\hline & & $\begin{array}{l}\text { learning disability } \\
\text { nurses }\end{array}$ & $\begin{array}{l}\text { *Mentors may lack } \\
\text { confidence about } \\
\text { their own clinical } \\
\text { knowledge and } \\
\text { experience. }\end{array}$ & $\begin{array}{l}\text { affecting the credibility } \\
\text { of the study. }\end{array}$ \\
\hline $\begin{array}{l}\text { Larocque } \\
. S, \\
\text { Luhanga. } \\
\text { FL, } \\
(2012)\end{array}$ & $\begin{array}{l}\text { To explore } \\
\text { the issue of } \\
\text { 'Failure to } \\
\text { fail' in a } \\
\text { nursing } \\
\text { program. } \\
\text { What are } \\
\text { the } \\
\text { perceptions } \\
\text { of nursing } \\
\text { mentors and } \\
\text { faculty } \\
\text { regarding } \\
\text { failure to fail } \\
\text { nursing } \\
\text { students } \\
\text { who display } \\
\text { unsafe or } \\
\text { poor } \\
\text { performanc } \\
\text { e? }\end{array}$ & $\begin{array}{l}\text { Qualitative } \\
\text { descriptive } \\
\text { design. } \\
\text { Individual semi- } \\
\text { structured } \\
\text { interviews, either } \\
\text { face to face or } \\
\text { telephone } \\
\text { interview. } \\
\\
\text { The sample size } \\
\text { was 13 } \\
\\
\text { Participants = } \\
\text { nursing university } \\
\text { faculty members; } \\
\text { preceptors and } \\
\text { faculty advisors. }\end{array}$ & $\begin{array}{l}\text { Five themes emerged } \\
\text { from this study:- } \\
\text { 1) Failing a student is } \\
\text { a difficult process. } \\
\text { 2) Both academic and } \\
\text { emotional support is } \\
\text { required for students, } \\
\text { preceptors and } \\
\text { faculty advisors. } \\
\text { 3) There are } \\
\text { consequences for } \\
\text { programs, faculty, } \\
\text { and students when a } \\
\text { student has failed a } \\
\text { placement. } \\
\text { 4) Occasionally, } \\
\text { personal, } \\
\text { professional, and } \\
\text { structural reasons } \\
\text { exist for failing to fail } \\
\text { a student. } \\
\text { 5) The reputation of } \\
\text { the professional } \\
\text { program can be } \\
\text { diminished as a result } \\
\text { of failing to fail a } \\
\text { student. }\end{array}$ & $\begin{array}{l}(+) \text { Credibility was } \\
\text { achieved by comparing } \\
\text { the analyses of } \\
\text { experienced } \\
\text { researchers. } \\
\text { (+) Used a wide range } \\
\text { of informants } \\
\text { increasing validity. } \\
\text { (+) Fittingness was } \\
\text { enhanced by collection } \\
\text { of data from different } \\
\text { settings. } \\
\text { (-)Not all mentors had } \\
\text { past experiences with } \\
\text { a student who had } \\
\text { failed or who was at } \\
\text { risk of failing, therefore } \\
\text { as they had not } \\
\text { experienced being in } \\
\text { that situation, this } \\
\text { could affect credibility. }\end{array}$ \\
\hline $\begin{array}{l}\text { Brown.L, } \\
\text { Douglas. } \\
\text { V, } \\
\text { Garrity.J, } \\
\text { Shepherd }\end{array}$ & $\begin{array}{l}\text { What } \\
\text { influences } \\
\text { mentors to } \\
\text { pass or fail } \\
\text { students. }\end{array}$ & $\begin{array}{l}\text { Quantative } \\
\text { Non-experimental } \\
\text { design using a } \\
\text { 29-item } \\
\text { questionnaire to }\end{array}$ & $\begin{array}{l}\text { 1) Could not prove } \\
\text { concern for failing the } \\
\text { student were valid. }\end{array}$ & $\begin{array}{l}\text { (+)large scale interview } \\
1790 \text { response rate out } \\
\text { of } 4341 \text { mentors } \\
\text { (participants) - across } \\
6 \text { health boards in }\end{array}$ \\
\hline
\end{tabular}


This document is the Accepted Manuscript version of a Published Work that appeared in final form in British Journal of Nursing, copyright (C) MA Healthcare, after peer review and technical editing by the publisher. To access the final edited and published work see https://doi.org/10.12968/bjon.2019.28.4.250.

\begin{tabular}{|c|c|c|c|c|}
\hline $\begin{array}{l}\text { United } \\
\text { Kingdom }\end{array}$ & $\begin{array}{l}\text { To establish } \\
\text { mentorship } \\
\text { practice in } \\
\text { relation to } \\
\text { pre- } \\
\text { registration } \\
\text { students. }\end{array}$ & $\begin{array}{l}\text { elicit data from } \\
\text { participants. } \\
\text { Sample size = 4, } \\
341 \text { mentors in } 6 \\
\text { NHS health } \\
\text { boards registered } \\
\text { on NMC } \\
\text { approved } \\
\text { databases } \\
\text { Participants = } \\
\text { Mentors working } \\
\text { across mental } \\
\text { health and adult } \\
\text { nursing in } \\
\text { community and } \\
\text { hospital settings }\end{array}$ & $\begin{array}{l}\text { 2) Gave student } \\
\text { benefit of the doubt } \\
\text { 3) Believed the } \\
\text { decision would be } \\
\text { over-turned by the } \\
\text { university. } \\
\text { 4) Lacked } \\
\text { confidence in dealing } \\
\text { with the situation of } \\
\text { failing the student. } \\
\text { 5) Concerned the } \\
\text { decision to fail would } \\
\text { not be supported } \\
\text { 6) Unclear about } \\
\text { paperwork after } \\
\text { failing student. } \\
\text { 7) Didn't want to hurt } \\
\text { the student's feelings. } \\
\text { Experiencing moral } \\
\text { stress. }\end{array}$ & $\begin{array}{l}\text { Scotland increasing } \\
\text { validity. } \\
(+) \text { Wide selection of } \\
\text { mentors; male, female, } \\
\text { ward based, } \\
\text { community increasing } \\
\text { validity. } \\
\text { (+)Pilot tested } \\
\text { increasing validity. }\end{array}$ \\
\hline $\begin{array}{l}\text { Black.S, } \\
\text { Curzio.J, } \\
\text { Terry.L, } \\
(2014)\end{array}$ & $\begin{array}{l}\text { To explore, } \\
\text { interpret } \\
\text { and develop } \\
\text { an } \\
\text { understandi } \\
\text { ng of } \\
\text { mentors' } \\
\text { experiences } \\
\text { of failing } \\
\text { pre- } \\
\text { registration } \\
\text { nursing } \\
\text { students in } \\
\text { their final } \\
\text { placement }\end{array}$ & $\begin{array}{l}\text { Qualitative. } \\
\text { Reflective } \\
\text { Interviews. } \\
\text { Sample size = } 19 \\
\text { Participants = } \\
\text { mentors from } 7 \\
\text { different health } \\
\text { care } \\
\text { organisations } \\
\text { covering both } \\
\text { inner city and } \\
\text { rural locations. }\end{array}$ & $\begin{array}{l}\text { 1) Feelings of guilt. } \\
\text { 2) Feelings that the } \\
\text { mentor has failed } \\
\text { also. } \\
\text { 3) Mentors } \\
\text { questioning their own } \\
\text { competence and } \\
\text { ability in practice. } \\
\text { 4) Stressful } \\
\text { experience. } \\
\text { 5) Personal and or } \\
\text { organisational } \\
\text { constraints/factors } \\
\text { which mentors felt }\end{array}$ & $\begin{array}{l}\text { (-) Only focuses on the } \\
\text { emotional/psychologic } \\
\text { al aspect when } \\
\text { actually failing a } \\
\text { student nurse. }\end{array}$ \\
\hline
\end{tabular}


This document is the Accepted Manuscript version of a Published Work that appeared in final form in British Journal of Nursing, copyright (C) MA Healthcare, after peer review and technical editing by the publisher. To access the final edited and published work see https://doi.org/10.12968/bjon.2019.28.4.250.

\begin{tabular}{|c|c|c|c|c|}
\hline & & & $\begin{array}{l}\text { inhibit them from } \\
\text { mentoring properly. }\end{array}$ & \\
\hline $\begin{array}{l}\text { Lawson. } \\
\text { L,(2010) } \\
\text { United } \\
\text { Kingdom }\end{array}$ & $\begin{array}{l}\text { To address } \\
\text { common } \\
\text { challenges } \\
\text { that allied } \\
\text { health } \\
\text { professional } \\
\text { s face as } \\
\text { clinical } \\
\text { educators } \\
\text { and identify } \\
\text { what } \\
\text { support is } \\
\text { required. }\end{array}$ & $\begin{array}{l}\text { Quantitative/Quali } \\
\text { tative (mixed } \\
\text { method) } \\
\text { Questionnaire } \\
\text { Focus Groups } \\
\text { All nurse mentors } \\
\text { (320) within } 2 \\
\text { Community } \\
\text { Trusts received a } \\
\text { questionnaire } \\
\text { Participants = } \\
\text { nurse mentors } \\
\text { allied health } \\
\text { professionals } \\
4 \text { structured focus } \\
\text { groups also took } \\
\text { place with } 67 \\
\text { total participants } \\
\end{array}$ & $\begin{array}{l}\text { 1) Difficult to fail a } \\
\text { student. } \\
\text { 2) Felt unable to } \\
\text { complete action plans } \\
\text { and documentation } \\
\text { objectively for fear of } \\
\text { upsetting the student } \\
\text { when wanting to fail } \\
\text { them. } \\
\text { 3) Mentors felt } \\
\text { unsupported by link } \\
\text { lecturers }\end{array}$ & $\begin{array}{l}\text { (+) Wide selection of } \\
\text { health professionals } \\
\text { selected to participate } \\
\text { in the study. } \\
\text { (-) Small scale study } \\
\text { (-) unpublished finding- } \\
\text { didn't seek ethical } \\
\text { approval. }\end{array}$ \\
\hline
\end{tabular}

Scrutiny of each paper was undertaken to identify key findings, outcomes and limitations. Potentially relevant concepts and ideas were highlighted and these were then grouped identifying re-occurring themes and concepts within and across the 
This document is the Accepted Manuscript version of a Published Work that appeared in final form in British Journal of Nursing, copyright (C) MA Healthcare, after peer review and technical editing by the publisher. To access the final edited and published work see https://doi.org/10.12968/bjon.2019.28.4.250.

studies. Three main themes emerged; the mentors' relationship with the university, documentation, and psychological and emotional impact.

\section{Discussion of themes}

Mentors' relationship with the University.

In the UK, universities are responsible for ensuring mentors are adequately supported to support the student via specified roles such as link lecturers and placement co-ordinators (MacIntosh 2015). This relationship should be formalised with regular contact and communication in order to addresses any issues or questions (Royal College of Nursing (RCN) 2007, 2015). The relationship and communication between the mentor and university staff was discussed in 4 out of the 5 studies (Lawson 2010; Jervis and Tilki 2011, Brown et al. 2012; Black et al. 2014). Respondents in both Jervis and Tilki's (2011) and Brown et al.'s (2012) studies reported that mentors feared that the university would overturn a decision to fail, and were worried about pressure from the university to pass a failing student. Jervis and Tilki (2011) indicated that this was based on mentors' past experiences of the university over-turning decisions. Respondents in Brown et al.'s (2012) study reported the same concern however this was not informed by past experiences.In addition, although Jervis and Tilki (2011) noted that this theme emerged from their study findings it was underexplored in their paper.

Lawson (2010), Larocque and Lahanga (2013) and Brown et al. (2012) also reported mentor concerns regarding the support they received from the university; a common 
This document is the Accepted Manuscript version of a Published Work that appeared in final form in British Journal of Nursing, copyright (C) MA Healthcare, after peer review and technical editing by the publisher. To access the final edited and published work see https://doi.org/10.12968/bjon.2019.28.4.250.

theme highlighted in earlier research (Duffy 2003; Scholes and Albarran 2005, Skingley et al. 2007). However, it is not clear whether all the 13 participants in Larocque and Lahanga's (2013) study had past experiences of mentoring a student who had failed or was at risk of failing. In contrast, Brown et al. (2012) found that only a small number of mentors in their study (144 out of 1790 participants) reported a problem with the relationship between mentors and the university. $68.2 \%$ (of 1790) mentors indicated that the academic practice partner (known as link lecturers in the UK) as being their first choice to approach if they encountered an under-achieving student. Mentors were also asked to rate the support they received from the university and although $9.5 \%$ (130) rated this as poor, on the whole (1243 out of 1373) mentors were satisfied with the support they received $(22.7 \%$ satisfactory; $38.3 \%$ good, $29.5 \%$ very good). This mixed methods study accessed mentors from 6 different publically funded NHS health boards. Almost 23\% (of 277) mentors who had passed a failing student reporting they had received poor support compared to $6 \%$ (of 1065) mentors who had failed a failing student.

\section{Documentation when failing a student}

Mentors must keep sufficient records to support and justify their decision of whether the student is fit to pass or fail (RCN 2007) and decisions made to fail a student must comply with professional guidance and document an appropriate action plan giving constructive feedback (NHS 2013). Stuart (2007) had previously highlighted that in some cases a decision to fail a student had been over-ridden by the examination board at the university due to poor documentation of the mentor. Brown et al. (2012) and Lawson (2010) reported similar issues. Lawson's (2010) study of a collaborative 
This document is the Accepted Manuscript version of a Published Work that appeared in final form in British Journal of Nursing, copyright (C) MA Healthcare, after peer review and technical editing by the publisher. To access the final edited and published work see https://doi.org/10.12968/bjon.2019.28.4.250.

project into the development of knowledge and skills of mentors sought feedback from 320 nursing mentors and found that despite regular mentor updates that included guidance in completing documentation, participants felt unable to fill out documentation of a failing student objectively. They did however feel capable of filling out documentation of an achieving student. Similarly, in Brown et al.'s study (2012) a small number of mentors (28 out of 277) who had passed a failing student felt unclear on how to complete the relevant documentation. This was also reflected in Duffy's (2003) seminal work in which inadequate support in relation to documentation completion sometimes led to failure to fail.

Psychological and emotional impact on mentors failing a student

Black et al. (2014) and Jervis and Tilki (2011) indicated that psychological and emotional pressures on mentors can be a barrier to failing a student. The 19 mentors in Black et al.'s (2014) study reported feelings of guilt which led to concerns regarding their abilities as a mentor and questioning their own competence and standards of assessment. Furthermore, mentors expressed psychological manifestations of stress and worry resulting in sleepless nights, exhaustion and effects on their general functioning. A similar impact was reported by Jervis and Tilki (2011) who also noted the pressure placed by students on mentors. These emotional demands were also cited earlier by Duffy (2003). It is likely that a poor relationship with academic partners would impact upon these anxieties (Brown et al. 2012), further undermining mentor confidence. Black et al. (2014) reported that some mentors were angry with other (previous) mentors for failing to address student performance earlier. 
This document is the Accepted Manuscript version of a Published Work that appeared in final form in British Journal of Nursing, copyright (C) MA Healthcare, after peer review and technical editing by the publisher. To access the final edited and published work see https://doi.org/10.12968/bjon.2019.28.4.250.

\section{Discussion}

The issue of 'failing to fail' features regularly in the UK literature and is informed by on-going concerns regarding assessment of student nurse competence and the implications for professional practice and patient safety (Burden et al 2017, Black et al. 2014, Clark et al. 2013). This review has shown that although there is some evidence regarding this topic and valid concerns regarding this issue in clinical practice, overall the quality and extent of the existing evidence does not fully explain this particular phenomena. Nor does it account for the substantive number of mentors who are confident in their assessment of students. Hunt et al. (2012) found that a larger number of students failed theory when compared to practice (a ratio of 4:1) and concluded that this offered some support to the argument that mentors were failing to fail underperforming students. However, assessing competence in practice is complex and subjective occurring in a high pressured environment in which individual mentor judgements may not lend themselves well to competency based assessment processes (Burden et al. 2017). Mentors have substantive professional knowledge and expertise in assessing students in clinical practice and this must be recognised and valued by their partner universities (National Nursing Research Unit (NNRU) 2013). When mentor decisions are over-turned or challenged by the university this can impact upon trust and respect, damage relationships and undermine confidence. Addressing perceived lack of support and enhancing confidence in decision-making is key to sustaining this relationship; issues also identified in a previous review (of literature 2003-11) by Elliott (2016). Mentors must liaise with university representatives if a student is at risk of being failed or there are concerns regarding competence (NHS 2013). This is essential to ensure that the psychological and emotional issues attached to failing a student nurse does not 
This document is the Accepted Manuscript version of a Published Work that appeared in final form in British Journal of Nursing, copyright (C) MA Healthcare, after peer review and technical editing by the publisher. To access the final edited and published work see https://doi.org/10.12968/bjon.2019.28.4.250.

discourage some mentors and that additional support and guidance with decisionmaking is provided. Both Black et al. (2014) and Jervis et al. (2011) indicated that this may be an area where practical support for mentors could be provided by peers and, or the university partner.

Although failing a student nurse in practice may be difficult, it is a necessary requirement of mentors and the majority remain confident in their ability to effectively undertake this role. Mentor concerns regarding failure to fail may be a consequence of other factors including mentor experience, relationship with the student and competing clinical demands (Elliott 2015). It is important that new mentors are supported in the early stages of their mentoring career until confidence and competence is established. Being an experienced nurse may not necessarily equate with 'experienced mentor', it could be argued that these are distinct roles and the skills and competencies required of mentors are different. The quality of the mentor may well depend upon whether this particular role has been chosen or not (Andrews et al. 2010; NNRU 2013). Since the guidance was issued by the NMC in 2008 , assessment has become a more substantive component of the mentor role (Andrews et al. 2010) and this role is increasingly being delivered within the context of on-going workforce retention issues and increased workloads and demands (Buchan et al 2017).

Future students in the UK will be supervised in clinical practice by any registered health or social care professional (NMC 2017) as opposed to the current situation where students are supervised and assessed by a registered nurse with mentor 
This document is the Accepted Manuscript version of a Published Work that appeared in final form in British Journal of Nursing, copyright (C) MA Healthcare, after peer review and technical editing by the publisher. To access the final edited and published work see https://doi.org/10.12968/bjon.2019.28.4.250.

status. The RCN (RCN 2017) has supported the NMC proposals and the benefits of inter-professional learning whilst highlighting the need for safeguards to ensure practice supervisors have the necessary knowledge, skills and experience to observe and supervise the student in practice (RCN 2017). Of concern however, is that the current requirement of a national training level for mentors and the maintenance of a mentor register is no longer advocated. Whilst any registered health care professional can supervise a student nurse, assessment will be solely the responsibility of a registered nurses undertaking one of two roles; 'nominated practice assessor' or 'nominated academic assessor' (NMC 2018). Roles and responsibilities will need to be clarified (RCN 2017). There does appear to be some merit in the splitting of these roles as it has long been recognised that combining supervision and assessment, with the responsibility for both traditionally falling to one individual mentor, does cause tension for many (Neary 2000).

This review has indicated that further focus is required on documentation. For universities, establishing stronger supportive relationship with their partners in practice is fundamental to safe and effective student learning and assessment and this should include proactive and pre-emptive approaches such as 'early warning systems' to identify potential difficulties. 'Failing to fail' does warrant further research and investigation that explores the range and extent of this phenomena in a systematic way. Key to further research in this area is ensuring that the perspectives of students and academic staff are also included in this research and debate. As this review focused on primary evidence (rather than other literature reviews), few research papers were identified to inform the review. Equally, using the term 'mentor' may well have limited the search to UK only studies as other terms may be more 
This document is the Accepted Manuscript version of a Published Work that appeared in final form in British Journal of Nursing, copyright (C) MA Healthcare, after peer review and technical editing by the publisher. To access the final edited and published work see https://doi.org/10.12968/bjon.2019.28.4.250.

culturally appropriate for supervisory and assessment arrangements in non UK countries.

\section{Conclusion}

There is some but limited evidence that the phenomena of 'failing to fail' a student nurse in the UK but arguably this is not as pervasive as previously suggested. Whilst this may be a concern and challenge for some mentors in practice, the majority are competent and comfortable in the decisions they make regarding student competence. Many universities have established and effective approaches to shared decision making regarding student competence in practice that are embedded in policy and practice. These should be and can be sufficient to address the assessment of competence in practice. 
This document is the Accepted Manuscript version of a Published Work that appeared in final form in British Journal of Nursing, copyright (C) MA Healthcare, after peer review and technical editing by the publisher. To access the final edited and published work see https://doi.org/10.12968/bjon.2019.28.4.250.

\section{References}

Aveyard.H, (2014) Doing a literature review in health and social care: a practical guide, $3^{\text {rd }}$ Ed, Maidenhead: OU Press

Andrews, M., Brewer, M., Buchan, T., Denne, and Hammond, J. (2010)

Implementation and sustainability of the nursing and midwifery standards for mentoring in the UK. Nurs Ed in Practice 10:251-255

Black.S, Curzio.J, Terry.L, (2014), Failing a student nurse: A new horizon of moral courage. Nurs Ethics 21(2): 224-238

Black, J. Allen, D. Redfern, L. Muzio, L. \& Round, B. (2008) Competencies in the context of entry level registered nurse practice. A collaborative project in Canada. Int Nurs Review. 55: 171-178.

Brown.L, Douglas.V, Garrity.J, Shepherd.CK, (2012) What influences mentors to pass or fail students. Nurs Management 19(5):16-21

Buchan J, Charlesworth A, Gerslick B and Seccombe I (2017) Rising Pressure: The NHS Workforce Challenge. Available from

\section{https://www.health.org.uk/publication/rising-pressure-nhs-workforce-challenge}

Burden S, Topping AE, O'Halloran C (2017) Mentor judgements and decision making in the assessment of student nurse competence: A mixed methods study. J Adv Nurs 74(5):1078-89

Cant R, McKenna L, Cooper S (2013) Assessing preregistration nursing students' clinical competence: A systematic review of objective measures. Int J of Nurs Practice 19:163-176 
This document is the Accepted Manuscript version of a Published Work that appeared in final form in British Journal of Nursing, copyright (C) MA Healthcare, after peer review and technical editing by the publisher. To access the final edited and published work see https://doi.org/10.12968/bjon.2019.28.4.250.

Clark, I. Trick, D. \& Loon, R. (2011) Academic reform: policy options or improving the quality and cost-effectiveness of undergraduate education in Ontario. Montreal and Kingston: McGill-Queens University Press.

Craig.JV, Smyth.RL, (2011),The Evidence-Based Practice Manual for Nurses, $3^{\text {rd }}$ ed, Edinburgh: Churchill Livingstone

Duffy, K. (2003) Failing students: a qualitative study of factors that influence the decisions regarding assessment of students' competence in practice. Available from: http://citeseerx.ist.psu.edu/viewdoc/download?doi=10.1.1.515.2467\&rep=rep1\&type $=\underline{\text { pdf }}$

Elliott C (2016) Identifying and managing underperformance in nursing students. Brit J of Nurs 25(5): 50-55

Foth, T. \& Holmes, H. (2016) Neoliberalism and the government of nursing through competency-based education. Nurs Inquiry (24) 1-9.

Francis, R. (2013) Report of the Mid Staffordshire NHS Foundation Trust Public Inquiry.

https://www.gov.uk/government/uploads/system/uploads/attachment data/file/27912 4/0947.pdf

Gainsbury.S, (2010), Nurse mentors still "failing to fail" students [online] Available at: http://tinyurl.com/ktptmfm

Garside, J. and Nhemachena (2013). A concept analysis of competence and its transition in nursing. Nurs Ed Today 33(5):541-545.

Gosport Independent Panel (2018) Gosport War Memorial Hospital: The Report of the Gosport Independent Panel 
This document is the Accepted Manuscript version of a Published Work that appeared in final form in British Journal of Nursing, copyright (C) MA Healthcare, after peer review and technical editing by the publisher. To access the final edited and published work see https://doi.org/10.12968/bjon.2019.28.4.250.

\section{https://www.gosportpanel.independent.gov.uk/media/documents/070618 CCS207}

\section{CCS03183220761 Gosport Inquiry Whole Document.pdf}

Gravina, E. (2017) Competency-Based Education and its Effect on Nursing

Education: A Literature Review. Teaching and Learning in Nurs 12:117-121.

Hawe.E, (2003), 'Its pretty difficult to fail': The reluctance of lecturers to award a failing grade. Assessment \& Evaluation in Higher Education 28(4): 371-382

Hunt.LA, McGee.P, Gutteridge.R, Hughes.M (2012) Assessment of student nurses in practice: A comparison of theoretical and practical assessment results in England. Nurs Ed Today 32: 351-5

Jervis.A, Tilki.M, (2011), Why are nurse mentors failing to fail student nurses who do not meet clinical performance standards? Brit J of Nurs 20(9): 582-587

Lankshear.A, (1990), Failure to fail: the teachers' dilemma. Nurs Stand 4(20):35-37

Larocque.S, luhanga.L, (2013), Exploring the issue of Failure to Fail in a Nursing Programme. Int J of Nurs Education Scholarship 10(1):1-8

Lawson.L, (2010), Final Project Report. Supporting Mentors and Clinical Educators: A collaborative project into the development of knowledge and skills to enhance clinical education practice, London: NHS

Luhanga.F, Myrick.F, Yonge.O, (2010) The preceptorship experience: an examination of ethical and accountability issues. J of Prof Nurs 26: 264-271

MacIntosh T (2015) The link lecturer role; inconsistent and incongruent realities, Nurs Ed Today 35(3) e8-e13 
This document is the Accepted Manuscript version of a Published Work that appeared in final form in British Journal of Nursing, copyright (C) MA Healthcare, after peer review and technical editing by the publisher. To access the final edited and published work see https://doi.org/10.12968/bjon.2019.28.4.250.

NHS (2013) Supporting the underachieving student a guide for mentors, Edinburgh: NHS

Neary, M (2000) Supporting students learning and professional development through the process of continuous assessment and mentorship Nurs Ed Today 20(6): 463474.

Nursing and Midwifery Board of Australia (2018) Framework for assessing standards for practice for registered nurses, enrolled nurses and midwives. Available at http://www.nursingmidwiferyboard.gov.au/Codes-Guidelines-

\section{Statements/Frameworks/Framework-for-assessing-national-competency-}

\section{standards.aspx}

NMC (2008), Standards to support learning and assessment in practice. NMC standards for mentors, practice teachers and teachers. 2nd ed, London, NMC NMC (2018) Standards of proficiency for registered nurses London: NMC Nursing and Midwifery Council (2018) Standards framework for nursing and midwifery education Available at https://www.nmc.org.uk/standards/standards-fornurses/

Paganini, M. and Egry, E. (2011). The ethical component of professional competence in nursing: An analysis. Nursing Ethics 18 (4) 571-582.

RCN (2007) Guidance for mentors of student nurses and midwives: An RCN Toolkit, London: RCN

RCN (2015) RCN Mentorship Project 2015 From Todays Support in Practice to Tomorrows Vision for Excellence, London: RCN 
This document is the Accepted Manuscript version of a Published Work that appeared in final form in British Journal of Nursing, copyright (C) MA Healthcare, after peer review and technical editing by the publisher. To access the final edited and published work see https://doi.org/10.12968/bjon.2019.28.4.250.

Royal College of Nursing (2017) Responses to the NMC Consultations on standards of proficiency for registered nurses. London: RCN.

Scanlan.JM, Care.WD, Gessler.S, (2001), Dealing with unsafe students in clinical practice, Nurs Educator 26(1):23-27

Scholes.J, Albarran.J,(2005), Failure to fail: facing the consequences of inaction. Nurs in Critical Care 10(3):113-115

Skingley, A. Arnott, J. Greaves, J. and Nabb, J. (2007) 'Supporting practice teachers to identify failing students'. Brit J of Comm Nurs 12(1):28-32

Stuart, C.C. (2007) Assessment, supervision, and support in clinical practice: a guide for nurses, midwives, and other health professionals, 2nd ed. Published Edinburgh; New York : Churchill Livingstone Elsevier

Tanicala.ML, Scheffer.BK, Roberts.MS, (2011) Defining pass/fail nursing student clinical behaviours phase 1: moving towards culture of safety, Nurs Ed Perspective 32(3):155-61

Zasadny M, F and Bull R, M (2015) Assessing competence in undergraduate nursing students: The Amalgamated Students Assessment in Practice model. Nurs Ed in Practice 15(2): 126-133 